\title{
MENINGKATKAN KEMAMPUAN BERFIKIR KREATIF MAHASISWA MELALUI MODEL PEMBELAJARAN INKUIRI
}

\author{
Sariana Marbun \\ Dosen Program Studi PG PAUD FIP UNIMED \\ Jl. Williem Iskandar Pasar V Medan Estate, Medan, Sumatera Utara,20371
}

Email: sariana.marbun1961@gmail.com

\begin{abstract}
Abstrak: Besuai dengan tingkat usia dan perkembangan kognitif mahasiswa seharusnya mahasiswa sudah memiliki kemampuan berfikir kreatif yang baik ketika sudah duduk dibangku perkuliahan. Namun Permasalahan yang terjadi pada mahasiswa yang baru maupun mahasiswa yang sudah melalui perkuliahan beberapa semester khususnya di Program Studi PG PAUD FIP Unimed pada umumnya memiliki kemampuan berfikir kreatif yang rendah. Salah satu upaya yang dapat dilakukan untuk meningkatkan kemampuan berfikir kreatif mahasiswa adalah melalui Penerapan Model Pembelajaran Inkuiri Secara umum penelitian ini bertujuan untuk meningkatkan kualitas proses dan hasil pembelajaran di Program Studi PG PAUD FIP Unimed, dan secara khusus penelitian ini bertujuan untuk meningkatkan Kemampuan Berpikir Kreatif Mahasiswa PG PAUD FIP Unimed melalui Penerapan Model Pembelajaran Inkuiri. Mahasiswa yang menjadi subjek penelitian ini adalah mahasiswa semester III TA.2018/2019 yang berjumlah 29 orang, dan target yang diharapkan $75 \%$ mahasiswa memiliki kemampuan berpikir kreatif yang baik. Disain penelitian ini menggunakan Penelitian Tindakan Kelas yang dilakukan melalui 2 siklus. Setiap siklus dilaksanakan selama dua kali pertemuan, dengan tahapan : 1) perencanaan, 2) tindakan, 3) observasi, dan 4) evaluasi/refleksi. Penelitian ini dilaksanakan selama 3 bulan. Hasil penelitian menunjukkan bahwa terjadi peningkatan kemampuan berpikir kreatif mahasiswa, walaupun tidak seperti target yang ditetapkan yaitu sebanyak 75\% mahasiswa memenuhi kriteria mampu berpikir kreatif. Dari beberapa indikator berpikir kreatif, ternyata hal yang sangat sulit dicapai mahasiswa adalah: (a) dalam hal memecahkan masalah dengan meninjaunya dari berbagai aspek; dan (b) mengajukan pertanyaanpertanyaan pada tingkat berpikir tinggi.
\end{abstract}

Kata Kunci : Kemampuan Berpikir Kreatif Mahasiswa, Model Pembelajaran

\section{PENDAHULUAN}

Berfikir merupakan instrument psikis yang paling penting. Dengan berfikir, maka manusia dapat dengan lebih mudah mengatasi kesulitan dan masalah hidup. Dalam proses mengatasi masalah manusia dapat berfikir dengan cara yang berbeda-beda, karena memang pada dasarnya ada beberapa cara berfikir, meski tidak semuanya efektif untuk memecahkan suatu masalah. Berfikir kreatif merupakan salah satu cara berfikir yang sangat dianjurkan untuk mengatasi suatu masalah. Karena dengan cara berfikir yang kreatif seseorang akan mampu melihat persoalan dari banyak segi dan persepsi, sehingga pada akhirnya akan 
dapat menghasilkan lebih banyak alternatif pemecahan masalah. Unsur kreatif memang sangat diperlukan dalam proses berfikir untuk menyelesaikan masalah. Berfikir kreatif merupakan cara berfikir yang menghasilkan suatu yang baru dalam konsep, pengertian, atau penemuan. Individu yang berfikir kreatif memiliki rasa ingin tahu yang tinggi, memiliki minat yang luas, memiliki aktifitas yang kreatif, memiliki percaya diri yang tinggi, cukup mandiri, berani mengambil resiko (tetapi dengan perhitungan) dalam melakukan sesuatu yang bagi mereka amat berarti, penting, dan disukai, mereka tidak terlalu menghiraukan kritik atau ejekan dari orang lain.

Berpikir kreatif pada peserta didik dapat dikembangkan sejak anak berada pada pendidikan usia dini, sampai pada tingkat perguruan tinggi. Pengembangan berfikir kreatif pada peserta didik dapat dilakukan guru pada setiap mata pelajaran apapun yang diterima peserta didik pada setiap jenjang pendidikan yang dilaluinya. Peserta didik yang terlatih dalam pengembangan berfikir kreatif selama dalam pembelajaran di sekolah, akan tampak prilakunya ketika mereka berada pada jenjang pendidikan di Perguruan Tinggi. Mahasiswa yang memiliki kemampuan berfikir kreatif, memiliki perhatian yang cukup tinggi dalam belajar, memiliki motivasi yang tinggi, berani mengajukan pertanyaan atau permasalahan, berani mengemukakan pendapat dalam memecahkan suatu persolan atau dalam menjawab pertanyaan, mandiri dalam belajar dan mengerjakan tugas-tugas, memiliki kemampuan berfikir divergen dalam memecahkan persolan.

Kenyataan yang terjadi di lapangan khususnya di Program Studi Pendidikan Guru Pendidikan Anak Usia Dini (PG-PAUD) FIP Unimed peneliti mengalami berbagai permasalahan. Pada saat kegiatan pembelajaran pada umumnya mahasiswa kurang memiliki semangat belajar yang tinggi, kurangnya motivasi untuk berperestasi, kurangnya inisiatif, kurang mau terlibat dan berpartisipasi secara aktif, kurang mau bekerja keras, kurang mau membuat sesuatu/tugas yang lebih baik, berpikirnya kurang kreatif, dan terlalu mengharapkan sesuatu atau materi perkuliahan yang diberi dosen. Pada sisi lain jika dilakukan tanya jawab atau diskusi kelas, mahasiswa cenderung lebih banyak diam, kalaupun ada yang berbicara hanya ada sekitar 5 orang dari 29 orang jumlah mahasiswa yang ada dalam satu kelas. Kenyataan ini juga terjadi pada mahasiswa yang telah berada di semester tinggi. Ketika mahasiswa berlatih berseminar pada mata kuliah seminar, mahasiswa kurang mampu menjabarkan isi makalah atau proposal penelitian yang mereka buat secara lisan walaupun telah dibantu dengan power-point yang mereka tayangkan. Jika ada pertanyaan yang meminta jawaban yang luas dari 
makalah/proposal yang disajikan, pada umumnya mahasiswa kurang mampu mengembangkan wawasan berfikirnya, sehingga mahasiswa terlalu berpusat pada teks yang ditulis, dan menjawabnya juga dengan membaca materi yang ada pada prin-out saja.

Analisa peneliti dari permasalahan yang terjadi pada mahasiswa PG PAUD yang dikemukakan di atas, menyimpulkan bahwa sejak mahasiswa berada di bangku sekolah dan selama perkuliahan mahasiswa kurang mengarahkan diri untuk mengembangkan kemampuan berfikir kreatif, mahasiawa terlalu terfokus untuk menyelesaikan tugas-tugas yang dikenal dengan enam tugas, disisi lain tugas-tugas mahasiswa yg telah dikserahkan ke dosen sebagian besar tidak mendapat respon atau feedback dari dosen. Pembelajaran masih kurang diarahkan pada pembelajaran yang mampu menemukan pengetahuan, menganalisis informasi maupun permasalahan dan memecahkan masalah. Dalam pembelajaran, mahasiswa kurang diarahkan pada pengembangan kemampuan berpikir kreatif dan kritis. Perkembangan ilmu pengetahuan dan teknologi yang sangat pesat saat ini menuntut semua mahasiswa harus memiliki keampuan berfikir kritis dan kreatif, agar mahasiswa mampu menghadapi tantangan dan permasalahan dalam kehidupan di masyarakat. Kemampuan berfikir kreatif dapat di kembangkan dengan berbagai cara baik secara individual maupun secara kelompok atau klasikal. Dalam pembelajaran salah satu model pembelajaran yang dapat dilakukan guru/dosen dalam mengembangkan kemampuan berfikir kreatif adalah dengan menerapkan model pembelajaran inkuiri.

Secara umum penelitian ini bertujuan untuk meningkatkan kualitas proses dan hasil pembelajaran di Program Studi PG PAUD FIP Unimed, dan secara khusus penelitian ini bertujuan untuk meningkatkan Kemampuan Berpikir Kreatif Mahasiswa Semester IV PG PAUD FIP Unimed melalui Penerapan Model Pembelajaran Inkuiri. Manfaat peraktis hasil penelitian ini adalah : (a) bagi dosen, menjadi masukan dalam rangka meningkatkan kualitas proses pembelajaran, khususnya dalam menerapkan model pembelajaran inkuiri; (b) Bagi Peneliti lainnya, dapat menjadi bahan masukan untuk melakukan penelitian yang sama pada jenjang pendidikan dan mata kuliah/mata pelajaran lainnya atau menindak lajuti hasil penelitian ini.

\section{KAJIAN TEORI}

Pembelajaran inkuiri bertujuan untuk memberikan cara bagi mahasiswa untuk membangun kecakapan-kecakapan intelektual (kecakapan berpikir) terkait dengan proses-proses berpikir reflektif. Model pembelajaran Inkuiri bertolak dari pandangan bahwa siswa sebagai subjek dan objek 
dalam belajar mempunyai kemampuan dasar untuk berkembang secara optimal sesuai dengan kemampuan yang dimilikinya. Proses pembelajaran harus dipandang sebagai stimulus yang dapat menantang siswa untuk melakukan kegiatan belajar.

Model pembelajaran inkuiri dipengaruhi oleh aliran kognitif yang memandang belajar pada hakikatnya adalah proses mental dan proses berpikir dengan memanfaatkan segala potensi yang dimiliki setiap individu secara optimal. Belajar tidak hanya sekedar proses menghafal dan memupuk ilmu pengetahuan, tetapi bagaimana pengetahuan yang diperolehnya bermakna untuk siswa melalui keterampilan berpikir.

Peranan guru lebih banyak menempatkan diri sebagai pembimbing atau pemimpin belajar dan fasilitator belajar. Dengan demikian, siswa lebih banyak melakukan kegiatan sendiri atau dalam bentuk kelompok memecahkan masalah. Sanjaya $(2008 ; 196)$ menyatakan bahwa ada beberapa hal yang menjadi ciri utama strategi pembelajaran inkuiri. Pertama, strategi inkuiri menekankan kepada aktifitas siswa secara maksimal untuk mencari dan menemukan, artinya pendekatan inkuiri menempatkan siswa sebagai subjek belajar.. Kedua, seluruh aktivitas yang dilakukan siswa diarahkan untuk mencari dan menemukan sendiri dari sesuatu yang dipertanyakan, sehingga diharapkan dapat menumbuhkan sikap percaya diri (self belief). Ketiga, tujuan dari penggunaan strategi pembelajaran inkuiri adalah mengembangkan kemampuan intelektual sebagai bagian dari proses mental, akibatnya dalam pembelajaran inkuiri siswa tidak hanya dituntut agar menguasai pelajaran, akan tetapi bagaimana mereka dapat menggunakan potensi yang dimilikinya.

Selanjutnya Sanjaya (2008:202-205) menyatakan bahwa pembelajaran inkuiri mengikuti langkah-langkah sebagai berikut:

1. Orientasi ; Pada tahap ini guru/dosen melakukan langkah untuk membina suasana atau iklim pembelajaran yang kondusif. Hal yang dilakukan dalam tahap orientasi ini adalah: a) menjelaskan topik, tujuan, dan hasil belajar yang diharapkan dapat dicapai oleh mahasiswa; b) menjelaskan pokok-pokok kegiatan yang harus dilakukan oleh siswa untuk mencapai tujuan; c) menjelaskan pentingnya topik dan kegiatan belajar, hal ini dilakukan dalam rangka memberikan motivasi belajar mahasiswa.

2. Merumuskan masalah; Merumuskan masalah merupakan langkah membawa siswa pada suatu persoalan yang mengandung teka-teki. Persoalan yang disajikan adalah persoalan yang menantang 
mahasiswa untuk memecahkan teka-teki itu. Teka-teki dalam rumusan masalah tentu ada jawabannya, dan mahasiswa didorong untuk mencari jawaban yang tepat. Proses mencari jawaban itulah yang sangat penting dalam pembelajaran inkuiri, oleh karena itu melalui proses tersebut mahasiswa akan memperoleh pengalaman yang sangat berharga sebagai upaya mengembangkan mental melalui proses berpikir.

3. Merumuskan hipotesis; Hipotesis adalah jawaban sementara dari suatu permasalahan yang dikaji. Sebagai jawaban sementara, hipotesis perlu diuji kebenarannya. Salah satu cara yang dapat dilakukan guru untuk mengembangkan kemampuan menebak (berhipotesis) pada setiap mahasiswa adalah dengan mengajukan berbagai pertanyaan yang dapat mendorong mahasiswa untuk dapat merumuskan jawaban sementara atau dapat merumuskan berbagai perkiraan kemungkinan jawaban dari suatu permasalahan yang dikaji.

4. Mengumpulkan data; Mengumpulkan data adalah aktifitas menjaring informasi yang dibutuhkan untuk menguji hipotesis yang diajukan. Dalam pembelajaran inkuiri, mengumpulkan data merupakan proses mental yang sangat penting dalam pengembangan intelektual. Proses pemgumpulan data bukan hanya memerlukan motivasi yang kuat dalam belajar, akan tetapi juga membutuhkan ketekunan dan kemampuan menggunakan potensi berpikirnya.

5. Menguji hipotesis; Menguji hipotesis adalah menentukan jawaban yang dianggap diterima sesuai dengan data atau informasi yang diperoleh berdasarkan pengumpulan data. Menguji hipotesis juga berarti mengembangkan kemampuan berpikir rasional. Artinya, kebenaran jawaban yang diberikan bukan hanya berdasarkan argumentasi, akan tetapi harus didukung oleh data yang ditemukan dan dapat dipertanggungjawabkan.

6. Merumuskan kesimpulan, yaitu proses mendeskripsikan temuan yang diperoleh berdasarkan hasil pengujian hipotesis. Untuk mencapai kesimpulan yang akurat sebaiknya guru/dosen mampu menunjukkan pada siswa/mahasiswa data mana yang relevan.

Berpikir kreatif sebagai kemampuan untuk melihat bermacammacam kemungkinan penyelesaian terhadap suatu masalah. Guilfrod (dalam Munandar, 1999) mengemukakan kemampuan berfikir kreatif merupakan bentuk pemikiran yang sampai saat ini masih kurang mendapat perhatian dalam pendidikan. Munandar (1999) mengemukakan seseorang yang memiliki kreativitas mempunyai ciri - ciri kepribadian yang dapat dilihat dari dua aspek. Pertama, Kemampuan Berpikir Kreatif ( aptitude), ciri-ciri yang 
tampak pada siswa adalah : a) Keterampilan berpikir lancar, yang ditandai dengan siswa sering mengajukan pertanyaan, menjawab pertanyaan dengan sejumlah jawaban, mempunyai banyak gagasan mengenai suatu masalah lancar mengungkapkan gagasan - gagasannya, bekerja lebih cepat, dapat dengan cepat melihat kesalahan atau kekurangan pada suatu obyek atau situasi; b) Keterampilan berpikir luwes (fleksibel), hal ditandai dengan anak memberikan aneka ragam penggunaan yang tidak lazim terhadap suatu obyek, memberikan macam - macam penafsiran terhadap suatu gambar, cerita, atau masalah, menerapkan suatu konsep dengan cara yang berbeda - beda, memberikan pertimbangan terhadap situasi yang berbeda dari orang lain, mendiskusikan suatu situasi selalu mempunyai posisi yang berbeda dari mayoritas kelompok, mampu mengubah arah berpikir secara spontan. c) Keterampilan berpikir orisinial. Hal ini ditandai dengan mahasiswa mampu memikirkan masalah - masalah atau hal - hal yang tidak pernah terpikirkan oleh orang lain ; mempertanyakan cara - cara lama dan berusaha memikirkan cara - cara baru; memilih simetri dalam menggambar atau membuat desain, memiliki cara berpikir yang lain dari yang lain, setelah membaca atau mendengar gagasan - gagasan, bekerja untuk menemukan penyelesaian yang baru, lebih senang mensintesis dari pada menganalisis situasi; c) Keterampilan memperinci, hal ini ditandai dengan siswa mencari arti yang lebih mendalam terhadap jawaban atau pemecahan masalah dengan melakukan langkah - langkah yang terperinci, memperkaya gagasan orang lain, menguji detail detail untuk melihat arah yang akan ditempuh, menambah garis garis , warna - warna dan bagian - bagian terhadap gambarnya sendiri atau gambar orang lain; d) Keterampilan menilai, hal ini ditandai dengan siswa memberi pertimbangan atas dasar sudut pandangnya sendiri, menentukan pendapat sendiri mengenai suatu hal, menganalisis masalah dengan selalu menanyakan "mengapa" ? mempunyai alasan yang dapat dipertanggung jawabkan untuk mencapai suatu keputusan, merancang suatu rancangan kerja dari gagasan - gagasan yang tercetus, menentukan pendapat dan bertahan terhadap pendapat tersebut. Kedua, Ciri - ciri Afektif ( Nonaptitude), ciri-ciri yang tampak pada siswa adalah : a) rasa ingin tahu; b) bersifat Imajinatif; c) sifat berani mengambil resiko. d) sifat menghargai.

Demikian juga Piers (dalam Ali dan Asrori, 2010) mengemukakan bahwa karakteristik kreativitas adalah: 1) memiliki dorongan (drive) yang tinggi, 2) memiliki keterlibatan yang tinggi, 3) memiliki rasa 
ingin tahu, 4) memilliki ketekunan yang tinggi, 5) cenderung tidak puas terhadap kemapanan, 6) penuh percaya diri, 7) memiliki kemandirian yang tinggi, 8) bebas dalam mengambil keputusan, 9) menerima diri sendiri, 10) senang humor, 11) memiliki intuisi yang tinggi, 12) cenderung tertarik kepada hal-hal yang kompleks, 13) toleran terhadap ambiguitas, 14) bersifat sensitive. Dari beberapa pendapat para ahli tentang ciri-ciri kreativitas dapat disimpulkan bahwa seorang yang kreatif, memiliki kecenderungan berprilaku: (a) tidak cepat bosan dalam belajar; (b) selalu menggali dan mencari informasi terutama hal-hal yang baru; (c) keinginan bertanya yang tinggi dan menjawab pertanyaan dengan jawaban yang luas; (d) mampu memecahkan masalah dengan meninjaunya dari berbagai aspek; (e) percaya diri yang tinggi; (f) mandiri; (g) kestabilan emosi. Orang yang kreatif dapat melihat satu persoalan dari berbagai sudut padang.

Berpikir kreatif dapat diartikan sebagai kemampuan seseorang untuk mengembangkan ide-ide baru, mencari cara kerja baru, cara pandang baru terhadap berbagai hal yang ada dalam diri dan lingkungannya. Maka orang yang berfikir kreatif biasanya juga menunjukkan keluwasan world view-nya. Orang yang berfikir kreatif selalu berhati lapang, karena cara pandangnya yang luas terhadap setiap persoalan, tidak akan terburu-buru untuk membuat kesimpulan tentang segala sesuatu, selalu menunjukkan kemampuannya untuk berbaik sangka terhadap segala hal, selalu berpikiran positip (positive thinking) terhadap segala hal, selalu berhati damai karena mampu mengontrol diri dan lingkungannya, tidak gampang tersulut emosinya, atau gampang patah hati ketika menghadapi persoalan. Berpikir kreatif adalah menggunakan kemampuan berpikir untuk membuat hubungan yang baru \& hubungan yang lebih berguna dari informasi yang sebelumnya sudah diketahui. Jadi berpikir kreatif tidak selalu menghasilkan sesuatu yang betul-betul baru melainkan bisa menghubungkan hal-hal yang sudah diketahui menjadi pengertian yang lebih sempurna.

\section{METODE PENELITIAN}

Disain penelitian ini menggunakan Penelitian Tindakan Kelas (PTK) dengan model Siklus yang dikemukakan Kemmis dan Mc.Tanggart, yaitu melalui 4 tahap. Tahapan tersebut adalah; (1) Tahap Perencanaan; (2) Tahap Tindakan; (3) Tahap Observasi; (4) dan Tahap Refleksi. Penelitian dilakukan pada Semester Genap Tahun Akademik 
2019/2020, yaitu pada mahasiswa yang berada pada semester empat khususnya pada mata kuliah Pengembangan Kurikulum AUD Program Studi Pendidikan Guru Pendidikan Anak Usia Dini (PG PAUD) FIP Unimed.

Penelitian ini dilakukan melalui Prosedur sebagai berikut : Dalam siklus pertama dilaksanakan kegiatan pembelajaran 2 kali pertemuan dan siklus kedua dilaksanakan kegiatan pembelajaran 2 kali pertemuan. Hasil dari siklus I digunakan sebagai acuan dalam menentukan perbaikan tindakan pada siklus II, sedangkan hasil dari siklus II akan digunakan sebagai acuan untuk melakukan tindakan berikutnya, atau kegiatan pembelajaran selanjutnya

Instrumen yang digunakan untuk melihat keberhasilan tindakan pada penelitian ini adalah : 1) Rancangan Pelaksanaan Perkuliahan, untuk melihat kemampuan dosen merancang pembelajaran dengan model pembelajaran Inkuiri; 2) Alat Penilaian Kemampuan Mengajar Dosen dengan penerapan pembelajaran Inkuiri pada mata kuliah Kompetensi Mengajar I; 2) Panduan Observasi, untuk mengukur kemampuan berpikir kreatif mahasiswa yang dilihat dari aktivitas belajar mahasiswa dalam pembelajaran dengan pendekatan Inkuiri. Panduan observasi disusun berdasarkan indicator berpikir kreatif mahasiswa, yaitu: (a) tidak cepat bosan dalam belajar; (b) selalu menggali dan mencari informasi terutama hal-hal yang baru; (c) keinginan bertanya yang tinggi; (c) menjawab pertanyaan dengan jawaban yang luas; (d) mampu memecahkan masalah dengan meninjaunya dari berbagai aspek; (e) percaya diri yang tinggi; (f) mandiri; dan (g) kestabilan emosi; 3) Tes hasil belajar, untuk mengukur penguasaan siswa terhadap materi yang telah dipelajari melalui model pembelajaran inkuiri. Data ini sebagai data tambahan untuk memperkuat data primer (berpikir kreatif mahasiswa).

Data yang terkumpul dianalisis dengan cara Persentase dan Deskriptif Kualitatif. Target yang yang ditetapkan adalah $75 \%$ kreativitas berpikir mahasiswa meningkat dengan diterapkannya model pembelajaran inkuiri dalam pembelajaran mata kuliah Kompetensi Mengajar I.

\section{HASIL PENELITIAN DAN PEMBAHASAN}

Berdasarkan pengamatan dan evaluasi/refleksi, serta analisis data yang telah dilakukan pada setiap aspek berpikir kreatif mahasiswa pada siklus I, maka hasil perubahan kemampuan berpikir kreatif mahasiswa dapat dilihat pada table dibawah ini. 
Tabel 1 : Kemampuan Berpikir Kreatif Mahasiswa sebelum Tindakan dan sesudah Tindakan I

\begin{tabular}{|c|c|c|c|c|c|}
\hline \multirow[b]{2}{*}{ No } & \multirow{2}{*}{$\begin{array}{c}\text { Aspek Kemampuan } \\
\text { Berpikir Kreatif Mahasiswa }\end{array}$} & \multicolumn{2}{|c|}{ Sebelum Tindk. } & \multicolumn{2}{|c|}{ SesudahTindk I } \\
\hline & & Jlh Mhs & $\%$ & JlhMhs & $\%$ \\
\hline 1 & Tidak cepat bosan dalam belajar & 12 org & $41 \%$ & 17 org & $59 \%$ \\
\hline 2 & $\begin{array}{l}\text { Menyampaikan informasi terbaru dalam } \\
\text { memecahkan permasalahan }\end{array}$ & 5 org & $17 \%$ & 6 org & $21 \%$ \\
\hline 3 & Keinginan bertanya yang tinggi & 6 org & $21 \%$ & 12 org & $43 \%$ \\
\hline 4 & $\begin{array}{l}\text { Menjawab pertanyaan dengan jawaban } \\
\text { yang luas }\end{array}$ & 5 org & $14 \%$ & 8 org & $27 \%$ \\
\hline 5 & $\begin{array}{l}\text { Memecahkan masalah dengan meninjau } \\
\text { dari berbagai aspek }\end{array}$ & 5 org & $17 \%$ & 8 org & $27 \%$ \\
\hline 6 & Percaya diri yang tinggi & 10 org & $29 \%$ & 14 org & $48 \%$ \\
\hline 7 & Pertanyaan tingkat tinggi & 5 org & $17 \%$ & 6 org & $21 \%$ \\
\hline 8 & $\begin{array}{l}\text { Keinginan menjawab pertanyaan dan } \\
\text { memberikan tanggapan }\end{array}$ & 8 org & $28 \%$ & 10 org & $34 \%$ \\
\hline 9 & Kestabilan emosi & 12 org & $41 \%$ & $17 \%$ & $58 \%$ \\
\hline
\end{tabular}

Dari table di atas dapat diketahui bahwa model pembelajaran inkuiri ternyata dapat meningkatkan kemampuan berpikir kreatif mahasiswa. Dari seluruh aspek kemampuan berpikir kreatif mahasiswa sebelum dilakukan tindakan terlihat bahwa jumlah mahasiswa yang memiliki kreativitas berpikir yang baik sangat rendah. Setelah dilakukan tindakan I terlihat terjadinya peningkatan jumlah mahasiswa pada setiap indikator kemampuan berpikir kreatif, walaupun peningkatan terjadi masih belum seperti yang ditargetkan pada penelitian ini. Dari beberapa indikator kemampuan berpikir kreatif mahasiswa, terlihat tingkat kebosanan, percaya diri yang tinggi dan kestabilan emosi mengalami perubahan yang lebih banyak pada mahasiswa jika dibandingkan dengan aspek lainnya, yaitu rata-rata 5 orang (14\%) yang meningkat kemampuannya pada ketiga aspek tersebut. Sementara pada aspek lainnya rata-rata mahasiswa yang mengalami peningkatan hanya 3 org $(8 \%)$.

Berdasarkan analisis dan refleksi yang telah dilakukan ditemukan bahwa masih rendahnya peningkatan kemampuan berpikir kreatif mahasiswa disebabkan beberapa factor, yaitu:

a. Belum terbiasanya mahasiswa belajar dengan memecahkan suatu permasalahan. Jika mahasiswa berdiskusi di kelas cenderung kurang mendapat pengawasan dari dosen hal ini terlihat pada saat mahasiswa berdiskusi secara berkelompok yang aktif berpikir hanya mahasiswa yang memang memiliki kemampuan berpikir yang baik saja, mahasiswa yang lainnya hanya mengikut saja.

b. Kemampuan bertanya jawab mahasiswa yang masih rendah terutama pada pertanyaan tingkat tinggi, dan menjawab serta memberi tanggapan dengan bahasa yang terstruktur, logis dan sistematis. 
c. Dosen pada saat kegiatan tanya jawab kurang melakukan kegiatan menggali agar mahasiswa mampu menjawab pertanyaan dengan jawaban yang luas, sehingga hanya mahasiswa yang memiliki kemampuan berpikir tinggi saja yang mampu menjawab pertanyaan secara luas.

Untuk memperoleh data tambahan berkaitan kemampuan berpikir kreatif mahasiswa, maka peneliti melakukan tes hasil belajar. Nilai tes hasil belajar mahasiwa menunjukkan bahwa, hanya 5 orang (17\%) mahasiswa yang memiliki nilai hasil belajar yang Baik Sekali (Nilai 90); sedangkan mahasiswa yang memperoleh nilai Baik (Nilai 80-85) sebanyak 13 orang (49\%); dan mahasiswa yang memperoleh nilai Cukup (70-78) sebanyak 11 orang (38\%). Jika dikaitkan dengan kemampuan berpikir kreatif mahasiswa, ternyata mahasiswa yang memiliki kemampuan berpikir yang baik (21\%) mencerminkan nilai hasil belajar yang diperolehnya melalui tes tertulis. Selanjutnya, mahasiswa yang dinyatakan kemampuan berpikir kreatifnya lemah, ternyata ketika di lakukan tes tertulis menunjukkan hasil belajar yang tidak terlalu rendah, karena seluruh mahasiswa mampu mencapai nilai batas kelulusan.

Pelaksanaan tindakan pada siklus II sama seperti yang dilakukan pada siklus I, hanya saja kelemahan-kelemahan pembelajaran yang terjadi pada siklus I menjadi penekanan untuk ditingkatkan pada saat pembelajaran di siklus II. Berdasarkan hasil observasi yang telah dilakukan, maka pada siklus II ini hal-hal yang terlihat adalah : a) Sebagian besar mahasiswa memiliki antusias belajar yang sangat baik, mahasiswa memiliki semangat belajar yang tinggi, dan semakin berani menyampaikan buah pikirannya ketika terjadi tanya jawab, walaupun dengan penggunaan sistematika bahasa yang belum maksimal. Hanya beberapa orang mahasiswa saja yang terlihat bosan dalam kegiatan pembelajaran; b) Sebagian mahasiswa masih sulit mengembangkan wawasannya berkaitan dengan permasalahan yang diajukan, mahasiswa hanya mampu menyampaikan idenya sesuai dengan yang ada dalam sumber bacaan yang mereka miliki, akan tetapi telah berusaha menggali informasi-informasi terbaru sehubungan dengan permasalahan yang diajukan; c) Ketika menjawab pertanyaan dari rekan-rekannya, sebagian mahasiswa belum mampu menjawab dengan bahasanya sendiri akan tetapi membacakan apa yang tertulis di kertas kerja mereka; d) Pada saat dosen mengajukan pertanyaan berkisar materi yang telah dipelajari yang ada kaitannnya dengan materi yang dibahas pada saat itu, pada umumnya mahasiswa sudah mulai ikut berpartsisipasi menjawab dan sangat antusias untuk terlibat membahas permasalahan yang diajukan setiap 
kelompok. Hal ini menunjukkan keberanian dan rasa percaya diri mahasiswa sudah semakin meningkat, walaupun jawaban yang disampaikan belum secara maksimal; e) Suatu hal yang sulit bagi mahasiswa untuk mengajukan pertanyaan-pertanyaan pada kategori pertanyaan tingkat tinggi, artinya hanya beberapa orang saja mahasiswa yang mampu mengajukan pada jenis pertanyaan tingkat tinggi dan sebagian besar pertanyaan-pertanyaan yang diajukan mahasiswa masih tergolong pada pertanyaan tingkat rendah. f) Keinginan tau mahasiswa tentang strategi pembelajaran yang dikembangkan semakin meningkat, hal ini terlihat pada umumnya mahasiwa berusaha turut berpartisipasi dalam pembelajaran, dan sangat serius turut serta menyelesaikan tahap demi tahap pada pembelajaran inkuiri; g) Berdasarkan kelemahan dosen pada siklus I, dalam pembelajaran terlihat dosen berusaha seoptimal mungkin melaksanakan langkah-langkah pembelajaran inkuiri sesuai dengan rancangan perkuliahan.

Berdasarkan analisis data yang telah dilakukan pada setiap aspek berpikir kreatif mahasiswa pada siklus II, maka hasil perubahan kemampuan berpikir kreatif mahasiswa dapat dilihat pada table dibawah ini.

Tabel 3. Kemampuan Berpikir Kreatif Mahasiswa pada Siklus I dan setelah dilakukan Siklus II

\begin{tabular}{|l|l|l|l|l|l|}
\hline \multirow{2}{*}{ No } & \multirow{2}{*}{$\begin{array}{c}\text { Aspek Kemampuan } \\
\text { Berpikir Kreatif Mahasiswa }\end{array}$} & \multicolumn{2}{c|}{ Siklus I. } & \multicolumn{2}{l|}{ Siklus II } \\
\cline { 3 - 6 } & Jlh Mhs & $\%$ & Jlh Mhs & $\%$ \\
\hline 1 & Tidak cepat bosan dalam belajar & 17 org & $59 \%$ & 24 org & \\
\hline 2 & $\begin{array}{l}\text { Menyampaikan informasi terbaru } \\
\text { dalam memecahkan permasalahan }\end{array}$ & 6 org & $21 \%$ & 10 org & $34 \%$ \\
\hline 3 & Keinginan bertanya yang tinggi & 12 org & $43 \%$ & 18 org & $62 \%$ \\
\hline 4 & $\begin{array}{l}\text { Menjawab pertanyaan dengan } \\
\text { jawaban yang luas }\end{array}$ & 8 org & $27 \%$ & 14 org & $48 \%$ \\
\hline 5 & $\begin{array}{l}\text { Memecahkan masalah dengan } \\
\text { meninjau dari berbagai aspek }\end{array}$ & 8 org & $27 \%$ & 11 org & $39 \%$ \\
\hline 6 & Percaya diri yang tinggi & 14 org & $48 \%$ & 22 org & $76 \%$ \\
\hline 7 & Pertanyaan tingkat tinggi & 6 org & $21 \%$ & 10 org & $38 \%$ \\
\hline 8 & $\begin{array}{l}\text { Keinginan menjawab pertanyaan } \\
\text { dan memberikan tanggap }\end{array}$ & 10 org & $34 \%$ & 18 org & $62 \%$ \\
\hline 17 & Kestabilan emosi & 17 org & $59 \%$ & 25 org & $86 \%$ \\
\hline
\end{tabular}

Dari table di atas dapat diketahui bahwa model pembelajaran inkuiri ternyata dapat meningkatkan kemampuan berpikir kreatif mahasiswa, walaupun peningkatan terjadi belum seperti target yang ditetapkan. Setelah dilakukan tindakan II terlihat terjadinya peningkatan jumlah mahasiswa pada setiap indikator kemampuan berpikir kreatif,. Dari 
beberapa indikator kemampuan berpikir kreatif mahasiswa terdapat tiga aspek berpikir kreatif yang meningkat secara baik, yaitu : (a) tidak cepat bosan dalam belajar, dari 59\% menjadi 83\%; (b) percaya diri yang tinggi, dari 48\% menjadi 76\%; (c) dan kestabilan emosi, dari 58\% menjadi $86 \%$. Selanjutnya, aspek yang mengalami peningkatan cukup baik juga terjadi pada: (a) keinginan bertanya yang tinggi dalam pembelajaran, dari $43 \%$ menjadi $62 \%$ dan; (b) keinginan menjawab pertanyaan dan memberikan tanggapan, yaitu dari $34 \%$ menjadi $62 \%$. Sementara itu pada aspek lainnya (menyampaikann informasi terbaru dalam memecahkan masalah, Memecahkan masalah dengan meninjau dari berbagai aspek, dan mengajukan pertanyaan tingkat tinggi) terjadi peningkatan namun masih pada kategori yang rendah, yaitu rata-rata hanya 4 org (13\%) mahasiswa yang mengalami peningkatan. Berdasarkan analisis dan refleksi yang telah dilakukan ditemukan bahwa masih belum berkembangnya kemampuan berpikir kreatif mahasiswa seperti yang ditargetkan (75\%) mahasiswa, adalah disebabkan beberapa faktor, antara lain adalah: (a) belum terbiasanya mahasiswa belajar dengan memecahkan suatu permasalahan, sehingga sulit untuk memotivasi diri melakukan perubahan; (b) kurangnya bimbingan, pengawasan, dan refleksi pada mahasiswa dari dosen pada saat mahasiswa berdiskusi secara berkelompok di kelas.

Untuk memperoleh data tambahan berkaitan kemampuan berpikir kreatif mahasiswa pada siklus II, maka peneliti melakukan tes hasil belajar. Nilai tes hasil belajar mahasiwa pada siklus II menunjukkan bahwa terjadi peningkatan nilai hasil belajar mahasiswa, yaitu yang memperoleh nilai Baik Sekali (nilai 90-95) dari 5 orang (17\%) menjadi 10 orang (34\%); sedangkan mahasiswa yang memperoleh nilai Baik (Nilai 80-88) dari 13 orang (45\%), dan mahasiswa yang memperoleh nilai Cukup (7078) sebanyak 11 orang (38\%) hanya tinggal 2 orang (0.06\%). Berkurangnya mahasiswa yang memperoleh nilai Cukup adalah karena ada mahasiswa yang telah meningkat nilainya menjadi Baik, demikian selanjutnya mahasiswa yang memiliki nilai baik pada siklus I ada yang ,meningkat nilainya menjadi Baik Sekali. Jika dikaitkan dengan kemampuan berpikir kreatif mahasiswa, ternyata mahasiswa yang memiliki kemampuan berpikir yang baik mencerminkan nilai hasil belajar yang baik dan baik sekali pada saat dilakukan tes hasil belajar. Selanjutnya, mahasiswa yang dinyatakan masih memiliki kemampuan berpikir kreatifnya lemah, ternyata ketika di lakukan tes tertulis menunjukkan hasil belajar yang masih cukup, karena seluruh mahasiswa mampu mencapai nilai batas kelulusan. 
Berdasarkan analisis data yang telah dikemukakan, dapat dinyatakan bahwa Penerapan Model Pembelajaran Inkuiri dapat meningkatkan Kemampuan Berpikir Kreatif Mahasiswa Semester Prodi PG PAUD FIP Unimed TA.2018/2010. Walaupun peningkatan kemampuan berpikir kreatif mahasiwa belum mencapai target yang ditetapkan yaitu $75 \%$ mahasiswa memiliki kemampuan berpikir kreatif, namun jika dilihat dari setiap aspek atau indikator kemampuan berpikir kreatif setiap mahasiswa sebelum dilakukan tindakan, tindakan di siklus I dan di siklus II mengalami perubahan kearah yang lebih baik. Demikian juga dengan tes hasil belajar, ternyata dengan meningkatnya kemampuan berpikir kreatif mahasiswa mengindikasikan terjadinya peningkatan kualitas hasil belajar mahasiswa.

Jika dianalisis lebih dalam, model pembelajaran inkuiri yang diterapkan dalam pembelajaran, teryata tidak hanya dapat meningkatkan kemampuan berpikir kreatif mahasiswa. Kenyataan peneliti menemukan bahwa aspek sosial atau kerjasama mahasiswa semakin meningkat, kemampuan berbahasa mahasiswa terlatih, terlihat mahasiswa semakin terampil dalam menungkapkan ide atau buah pikirannya. dan struktur bahasa yang digunakan mahasiswa semakin baik. Mahasiswa lebih aktif dalam belajar, karena semua turut berpartisipasi mulai dari merumuskan masalah, menetapkan hipotesis, pengumpulan data sampai pada mahasiswa menguji hipotesis dan membuat kesimpulan. Pembelajaran sangat mengasikkan dan menyenangkan bagi mahasiswa, walau diawal pembelajaran mahasiswa kurang bersemangat, akan tetapi setelah di pertemuan kedua pada siklus I tampak motivasi belajar mahasiswa semakin meningkat.

Beberapa pendapat yang menyatakan bahwa model pembelajaran inkuiri hanya dapat diterapkan pada mata pelajaran Sains/IPA, dan Matematika atau pada bidang Eksakta saja, ternyata tidak benar. Model pembelajaran inkuiri ternyata dapat diterapkan pada mata pelajaran/mata kuliah yang berada pada rumpun ilmu sosial. Demikian juga beberapa teori yang menyatakan bahwa model pembelajaran Inkuiri memiliki banyak keuntungan (Mulyasa, 2006) ternyata benar. Penerapan model pembelajaran inkuiri ternyata; (a) dapat mengembangkan kemampuan kognitif, afektif, dan psikomotor secara seimbang, sehingga pembelajaran lebih bermakna; (b) memberikan ruang kepada mahasiswa untuk belajar sesuai dengan gaya belajar mereka; (c) dianggap sebagai strategi yang pembelajaran yang sesuai dengan psikologi belajar modern yang mengganggap belajar adalah proses perubahan tinglkah laku berkat adanya pengalaman; dan (d) melayani kebutuhan siswa yang memiliki 
kemampuan di atas rata-rata tidak akan terhambat oleh siswa yang lemah dalam belajar.

\section{SIMPULAN}

Berdasarkan hasil analisis data dan pembahasan hasil penelitian maka disimpulkan:

1. Model Pembelajaran Inkuiri merupakan salah satu model pembelajaran yang dapat meningkatkan kemampuan berpikir kreatif mahasiswa. Hal ini dapat dilihat terjadinya peningkatan pada 9 indikator kemampuan berpikir kreatif mahasiswa sebelum dilakukan tindakan, setelah dilakukan tindakan pada siklius I, dan setelah dilakukan tindakan pada siklus II yaitu: a) Tidak cepat bosan dalam belajar; b) menyampaikan informasi terbaru dalam pemecahan masalah; c) keinginan bertanya yang tinggi; d) menjawab pertanyaan dengan jawaban yang luas; e) memecahkan masalah dengan meninjau dari berbagai aspek; f) percaya diri yang tinggi; g) mengajukan pertanyaan pada tingkat tinggi; h) keinginan menjawab pertanyaan dan memberikan tanggapan; i) kestabilan emosi.

2. Penerapan model pembelajaran inkuiri ternyata dapat meningkatkan kualitas hasil belajar mahasiswa pada aspek kognitif, afektif dan psikomotorik.

3. Penerapan model pembelajaran inkuiri ternyata dapat meningkatkan aktivitas, dan motivasi belajar mahasiswa, sehingga dapat tercipta pembelajaran yang aktif, kreatif, efektif dan menyenangkan (PAKEM).

Hasil penelitian ini hendaknya dapat dijadikan masukan bagi dosen lain dalam upaya meningkatkan kualitas proses dan hasil belajar mahasiswa, khususnya para dosen di Program Studi PG- PAUD FIP Unimed.

\section{DAFTAR PUSTAKA}

Daryanto. 2010. Belajar dan Mengajar. Bandung : Yerama Widya.

Dewi. Rosmala.2010. Penelitian Tindakan Kelas. Pasca Sarjana Unimed

Hamalik, Oemar. 2010. Proses Belajar Mengajar. Jakarta, BumiAksara.

Munandar, Utami .2009. Pengembangan Kreativitas Anak Berbakat. Jakarta : Rineka Cipta.

Sanjaya, Wina. 2006. Strategi Pembelajaran Berorientasi Standart Proses Pendidikan. Jakarta : Kencana. 
2005. Pembelajaran dalam Implementasi KBK. Jakarta, Kencana Prenada Media Group.

Sutikno ,M Sobry. 2005. Pembelajaran Efektif. Mataram, NTP Pres.

Rusman. 2010. Model- model Pembelajaran Mengembangkan Profesionalisme Guru. Jakarta: Raja Grafindo Persada

Trianto . 2009. Medesain Model Pembelajaran Inovatif- Progresif. Jakarta: Kencana.

Uno, Hamzah B. 2011. Model Pembelajaran; Menciptakan Proses Belajar Mengajar yang Kreatif dan Efekltif. Jakarta, Bumi Aksara.

Wena, Made. 2009. Strategi Pembelajaran Inovatif Kontemporer. Jakarta, Bumi Aksara. 